\title{
Richard B. Johnston Jr.: Unravelling the Secrets of Neonatal Host Defense
}

\author{
Christian P. Speer ${ }^{a}$ Henry L. Halliday ${ }^{b}$ \\ a University Children's Hospital, University of Würzburg, Würzburg, Germany;

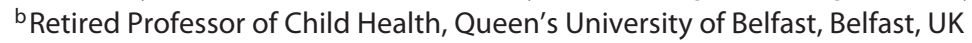

Richard B. Johnston Jr. (Dick) was born in Atlanta, GA, in 1935 as the eldest of four brothers. There were no physicians in his family, but his father, a salesman, encouraged his interest in medicine, and his mother, a poet, guided his values towards trying to make the world a better place. His grandfather advised him at age 14, "If you really want to help people, go into medicine."

He exhibited leadership early as the president of his high school, captain of the football team, and teacherselected, most outstanding graduate. He majored in philosophy at Vanderbilt University, Nashville, where the student body voted him the most outstanding graduate. He later attended Vanderbilt Medical School, followed by 2 years of pediatric residency there during which he also functioned as a postdoctoral fellow with Mildred Stahlman, a pioneer in contemporary neonatology. Neonatology boards did not exist at that time. The first of his eight papers in the New England Journal of Medicine and two papers on neonatal bacteremia came from work during this residency fellowship. Particularly important were his meeting with Mary Anne, now his wife of 59 years, and the birth of their first son, now an orthopedic surgeon.

Dick Johnston continued his pediatric residency at Children's Hospital, Boston, where he witnessed the unsuccessful attempt to save President John Kennedy's son, born weighing 2,110 g but suffering from hyaline membrane disease [1]. He moved next to serve as a pediatrician at the US Army Hospital, Bad Cannstatt, Germany, a period that he regards as equivalent to additional, highly

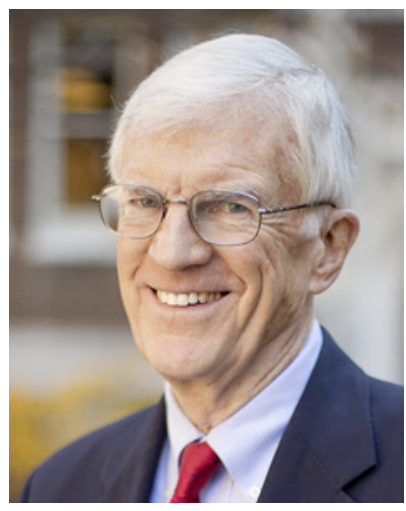

Richard B. Johnston Jr.

fulfilling years of college courses in the humanities - exposure to European history, architecture, art, languages, and the cultures of its people, especially those of Germany. Their second son, born in Bad Cannstatt, is now Dean of Dell Medical School, University of Texas, Austin.

After return to the US, he began 3 years of postdoctoral education in clinical and basic science immunology at Boston Children's Hospital and Harvard University. Their daughter, now a clinical psychologist, was born there. He began his academic career in 1970 at the University of Alabama (UAB), Birmingham. His research goal from the beginning was to understand the biologic mechanisms responsible for protection against infection, with the hope that they might ultimately be manipulated to improve the immune response. This led to pioneering 
work in the biology of neutrophils, monocytes, macrophages, and the complement system, and in the exploitation of immunodeficiency diseases as "experiments of nature" capable of exposing fundamental mechanisms of host defense.

Examples of his work during the Boston-UAB period included the development of the first quantitative assay of bacterial phagocytosis and demonstration for the first time that phagocytosis of pathogenic bacteria requires fixation to the organism by the complement system [2]; demonstration that the defective opsonization of pneumococci by serum from children with sickle cell disease is due to deficiency of the alternative pathway of complement, at least partially explaining the predisposition to lethal pneumococcal infection in this population [3]. Moreover, he provided first evidence suggesting that mammalian cells can produce hydroxyl radical, the most reactive by-product of oxygen metabolism [4]; that neutrophils [5] and monocytes [6] encountering opsonized bacteria or immune complexes release large amounts of toxic oxygen by-products to the outside, implicating the phagocyte respiratory burst in the pathogenesis of rheumatologic disease and inflammation. He also performed the immunologic assays fundamental to the development of the vaccine against Haemophilus influenzae disease [7].

During a year at Rockefeller University, New York, and after his move to the chair of pediatrics at National Jewish Hospital, Denver, he shifted his focus to macrophage biology. He demonstrated that tissue macrophages depend on the respiratory burst for microbial killing [8, 9]; that these cells can be "activated" by exposure to bacterial products for a more potent respiratory burst and microbicidal activity $[8,9]$; that activation results from an increase in the Vmax and decrease in the $\mathrm{Km}$ of the oxidant-producing NADPH oxidase [10]; that multinucleated giant cells function in host defense in every way as macrophages [11]; and that neutrophils can be activated by bacterial products for enhanced function and are not an end-stage cell incapable of modification outside the bone marrow, as previously understood [12]. His over 300 publications were accomplished largely through the work of postdoctoral colleagues from North and South America, Europe, Africa, India, Australia, New Zealand, and Japan. Of these publications, 38 dealt with host defense in the neonate.

Richard B. Johnston contributed to academic pediatrics through his elected service as President of the Society for Pediatric Research (SPR) (1980) and the American Pediatric Society (APS) (1996). The principal concern of SPR membership at the time of his election was the poor

Richard B. Johnston Jr.: Unravelling the

Secrets of Neonatal Host Defense quality of Pediatric Research, the journal owned by the SPR, APS, and European Society for Paediatric Research and fiscally managed by the International Pediatric Foundation (IPRF). The journal editor served an unlimited term with sole control of all aspects of editorial policy and paper selection. With the support of the SPR and APS Councils, he led reorganization of the journal's management to its current form, with North American and European editors, 5-year rotating terms of editorship with a local editorial board, and closer integration of societies and the IRPF [13].

When elected President of the APS, its sole function with the SPR was to organize an annual meeting. Reasoning that this was a waste of the leadership strength of academic pediatrics in promoting child health, he led the Council in creating goals for meaningful participation of the Society in promoting child health. Before the annual meeting of his presidency (1997), he asked members registered for the meeting to join one of seven working groups to meet on the first half-day to develop specific APS initiatives, including strengthening research, developing leadership, particularly in women, and strengthening advocacy [14]. Each working group developed a concrete product, leading the APS towards an active role in improving child health, a role that he emphasized again in his address on receipt of the Society's Howland Award [15]. He extended this message of involvement in 2018 to all physicians and their societies, with a focus on public education [16]. Furthermore, at the 1997 meeting, he began the traditions of a members' dinner and a lecture by the recipient of the March of Dimes Prize in Developmental Biology.

After serving as Chair of Pediatrics at Children's Hospital of Philadelphia, Dick Johnston continued his research at Yale University, New Haven, and became Medical Director of the March of Dimes, being attracted by its mission to prevent birth defects and prematurity. He established the Foundation's first large, multi-year grant program to explore the molecular basis of preterm labor. Perhaps Dick Johnston's biggest contribution to child health was his major role in the collaboration with the Centers for Disease Control (CDC), in obtaining FDAmandated folic acid fortification of grain products (FAF). Recent estimates worldwide indicate that FAF prevents birth with spina bifida in at least 50,000 babies a year.

He chaired advisory committees for the FDA, CDC, Howard Hughes Medical Institute, and Canadian Institute for Health Research, and seven committee reports for the National Academy of Medicine (NAM). His honors include the Harvey Wiley Medal from the FDA, the David 
Rall Medal from the NAM, of which he is a member, and the John Howland Medal from the APS.

Richard B. Johnston is an outstanding and dedicated pediatrician, scientist, and academic teacher. With his charming, humorous, and caring personality and his exemplary, disciplined behavior he has intellectually chal- lenged and supported numerous young pediatricians in critical and objective thinking. Personally, I (C.P.S.) owe him a lot, and I am most grateful that he has accepted to be honored at RECENT ADVANCES IN NEONATAL MEDICINE 2020, and wholeheartedly I wish him many more years of active academic work.

\section{References}

1 Johnston RB Jr. President Kennedy's baby: Born too soon for the miracle. In: Rotbart H, editor. Miracles We Have Seen. Deerfield (FL): Health Communications, Inc; 2016. pp. 201-4.

2 Johnston RB Jr, Klemperer MR, Alper CA, Rosen FS. The enhancement of bacterial phagocytosis by serum. The role of complement components and two cofactors. J Exp Med. 1969 Jun;129(6):1275-90.

3 Johnston RB Jr, Newman SL, Struth AG. An abnormality of the alternate pathway of complement activation in sickle-cell disease. $\mathrm{N}$ Engl J Med. 1973 Apr;288(16):803-8.

4 Johnston RB Jr, Keele BB Jr, Misra HP, Lehmeyer JE, Webb LS, Baehner RL, et al. The role of superoxide anion generation in phagocytic bactericidal activity. Studies with nor$\mathrm{mal}$ and chronic granulomatous disease leukocytes. J Clin Invest. 1975 Jun;55(6):135772.

5 Johnston RB Jr, Lehmeyer JE. Elaboration of toxic oxygen by-products by neutrophils in a model of immune complex disease. J Clin Invest. 1976 Apr;57(4):836-41.
6 Johnston RB Jr, Lehmeyer JE, Guthrie LA. Generation of superoxide anion and chemiluminescence by human monocytes during phagocytosis and on contact with surfacebound immunoglobulin G. J Exp Med. 1976 Jun;143(6):1551-6.

7 Anderson P, Johnston RB Jr, Smith DH. Human serum activities against Hemophilus influenzae, type b. J Clin Invest. 1972 Jan;51(1): 31-8.

8 Johnston RB Jr, Godzik CA, Cohn ZA. Increased superoxide anion production by immunologically activated and chemically elicited macrophages. J Exp Med. 1978 Jul;148(1): 115-27.

9 Sasada M, Johnston RB Jr. Macrophage microbicidal activity. Correlation between phagocytosis-associated oxidative metabolism and the killing of Candida by macrophages. J Exp Med. 1980 Jul;152(1):85-98.

10 Sasada M, Pabst MJ, Johnston RB Jr. Activation of mouse peritoneal macrophages by lipopolysaccharide alters the kinetic parameters of the superoxide-producing NADPH oxidase. J Biol Chem. 1983 Aug;258(16):9631-5.

11 Schlesinger L, Musson RA, Johnston RB Jr. Functional and biochemical studies of multinucleated giant cells derived from the culture of human monocytes. J Exp Med. 1984 Apr; 159(4):1289-94.
12 Guthrie LA, McPhail LC, Henson PM, Johnston RB Jr. Priming of neutrophils for enhanced release of oxygen metabolites by bacterial lipopolysaccharide. Evidence for increased activity of the superoxide-producing enzyme. J Exp Med. 1984 Dec;160(6):165671.

13 Johnston RB Jr. The impact of research in pediatrics on the health of children. Pediatr Res. 1981 Dec;15(12):1465-7.

14 Johnston RB Jr. American Pediatric Society Presidential Address 1997: The ever-whirling wheel of change. Pediatr Res. 1997 Dec;42(6): 909-12.

15 Johnston RB Jr. American Pediatric Society's 2008 John Howland award acceptance lecture: life goals for academic pediatrics. Pediatr Res. 2008 Sep;64(3):320-2.

16 Johnston RB Jr. Poor education predicts poor health-a challenge unmet by American Medicine. NAM Perspectives. Commentary, National Academy of Medicine, Washington, DC. Available from: https://doi.org/https:// doi.org/10.31478/201904a. 